\title{
EWOLUCJE I REWOLUCJE W WYBRANYCH GATUNKACH DZIENNIKARSKICH PO 1989 ROKU (REPORTAŻ I ARTYKUE WIRALOWY)
}

Od dawna wiadomo, że przemiany społeczno-polityczne wyznaczają artystom i dziennikarzom drogę rozwoju. ${ }^{1} \mathrm{Z}$ jednej strony brak wolności słowa prowadził i prowadzi do eksperymentów trudno zrozumiałych dla zwykłych odbiorców (stosowanie podtekstów, wieloznaczność wypowiedzi, hermetyczność przekazu), z drugiej natomiast zbytnia wolność rozleniwia i nie zmusza do stosowania wyszukanych form przekazu. Mówienie o rzeczywistości jest sztuką. O rzeczywistości mówią artyści, pisarze, ale także dziennikarze, którzy pokazują ją słowem (prasowi), dźwiękiem (radiowi) i obrazem (telewizyjni).

W minionych trzech dekadach, pod wpływem rozwoju technik elektronicznych i zmiany świadomości odbiorców mediów dzięki wolności słowa, doszło do ewolucji w rozwoju reportażu. W gatunkach dziennikarskich nastąpiła także swego rodzaju rewolucja. Pojawił się bowiem nowy gatunek - artykuł wiralowy, który nieoczekiwanie zrobił szybką i wielką karierę.

\section{REPORTAŻ}

W latach 1945-1989 w Polsce Ludowej ówczesna władza narzuciła twórcom kultury, a więc i dziennikarzom, wzory mówienia o rzeczywistości. Nie wolno im było dzielić się spostrzeżeniami wprost, tak jak je przeżywali, pokazywać zła systemu autorytarnego, przedstawiać prawdy. Stosowali kamuflaż. ${ }^{2}$ Najbardziej widoczny zakamuflowany przekaz można było dostrzec w reportażu. Kamuflaż polegał na tym, że dziennikarze, reporterzy korzystali $z$ chwytów znanych literaturze ${ }^{3}$ (obrazowanie, gry słowne, prawdopodobieństwo). Tak pisali m.in. Melchior

1 Por. Burkot 1984, Kleiner 1990, Matuszewski 1992, Święch 1997, Markiewicz 1999, Wolny 1991.

2 Por. Bereś 2004, 11-12 oraz Wolny-Zmorzyński 2004, 72.

3 Tamże. 
Wańkowicz, Stefan Kozicki, Joanna Siedlecka, Barbara N. Łopieńska, Jerzy Lovell, Romuald Karaś, Ryszard Kapuściński. Stworzyli poetykę reportażu, czerpiąc najlepsze wzory z literatury polskiej i obcej (m.in. Henryk Sienkiewicz, Fiodor Dostojewski, Ernest Hemingway). Ich reportaże czyta się, nawet po siedemdziesięciu latach od chwili publikacji, z nie mniejszym zainteresowaniem, niż czytali je współcześni, którzy ciekawi byli danego zdarzenia. Reportaż pisany zastępował dzisiejszą wszechobecną telewizję. Reporter musiał więc odtworzyć zdarzenia, wywołać obrazy, przywołać bohaterów. Reporterzy, chcąc nie chcac, korzystali $z$ chwytów literackich, by jak najwierniej i obrazowo opowiedzieć o zdarzeniach.

Po 1989 roku reporterzy, odchodząc od przyzwyczajeń mijającej, autorytarnej epoki, zaczęli dokonywać zmian w poetyce gatunku. Zmiany te dotykaja następujących sfer:

- tematu podejmowanego przez reporterów;

- formy (budowy, kształtu);

- języka;

- postaw reportera;

- nośników.

Zmiany w sferze tematu zależą od sytuacji politycznej, społecznej, gospodarczej, obyczajowej. Dziś łatwiej jest pisać o homoseksualistach, transwestytach, wszelkich upodobaniach seksualnych, czytamy o tym np. w reportażu z Hiszpanii Aleksandry Lipczyk Ludzie z placu słońca [2017].

Ponad 25 lat temu, gdy Mariusz Szczygieł napisał oficjalnie i bez zahamowań o onanizmie w reportażu Onanizm polski (wydanym w 1996 r. w książce Niedziela, która zdarzyła się $w$ środę) - spotkało się to z krytyka i potępieniem obyczajowym. Ponad trzydzieści lat temu nie można było podejmować i ujawniać tematów dotyczacych działań milicji obywatelskiej i służby bezpieczeństwa. Obecnie, dokładnie: pięć lat temu, napisała o tym Anna Kłys w obszernym, mającym książkowa formę reportażu Brudne serca. Jak zafałszowaliśmy historię chłopców z lasu i ubeków. Napisała prawdę, która pokazała jej rodzonego ojca jako „prześladowcę chłopców z lasu”. Natomiast Magdalena Grzebałkowska w książce 1945. Wojna i pokój [2015] zawarła opowieść o wypędzeniach Niemców i wypędzeniach Polaków ze Śląska, Mazur i Pomorza, a Krzysztof Ziemiec w reportażu Wysiedleni. Akcja „Wisła” 1947 [2017] - o wysiedleniach ludności ukraińskiej z południowo-wschodniej Polski w 1947 roku na tereny zachodnie.

W latach osiemdziesiatych XX wieku o działaniach Armii Krajowej pisano sporadycznie, do popularnych reporterów należał natomiast np. Cezary Chlebowski, przedstawiajacy historię i działania Armii Ludowej i Batalionów Chłopskich. Po 1989 roku reporterzy podejmują otwarcie wszelkie tematy historyczne, odsłaniaja problemy trudne i niewygodne, niekiedy za swój obowiązek uznając informowanie o tym, co inni chca 
ukryć. Mogą wreszcie rozliczać przedstawicieli władzy z wszelkiego rodzaju nadużyć i uprawiać także $z$ powodzeniem dziennikarstwo śledcze (m.in. Jerzy Jachowicz, Anna Marszałek, Witold Gadomski, Marek Balawajder, Tomasz Patora, Wojciech Sumliński).

Jeśli chodzi o zmiany w sferze formy - zbliżaja reportaż do feature. Ta nazwa wypowiedzi prasowej jest znana w USA od lat przedwojennych, a od lat sześćdziesiątych XX wieku - na zachodzie Europy. Feature oznacza relację, która prócz podstawowych faktów o rzeczywistości realnej zawiera szczegóły uboczne tworzace niejako tło informacyjne wydarzeń. Autor wychwytuje $z$ garści faktów najistotniejszy aspekt sprawy i na nim się skupia. Feature wprawdzie - podobnie jak reportaż - zajmuje się wycinkiem rzeczywistości, takim, który wskazuje nie na cały obraz życia ludzkiego, ale na jego istotny dla odbiorcy fragment. Feature odmiennie niż reportaż (w reportażu kompozycja jest luźniejsza; jest możliwość stosowania inwersji), ujmuje fakty zgodnie $z$ chronologicznym ich przebiegiem. Autor feature opisuje zdarzenia, ale w sposób zdawkowy, wybiórczy. Ogranicza się do uwag, określających zachowanie postaci. Typologia feature pozwala dziennikarzowi prześlizgiwać się po zdarzeniach, pobieżnie orientując czytelnika w tematyce zagadnienia. To, czego nie powie sam reporter, zastapione jest najczęściej fotografiami bohaterów oraz miejsc, gdzie zdarzenia się odbywały. ${ }^{4}$ Czytelnik nie wyczuwa obecności autora feature. Jego subiektywne nastawienie do opisywanych wypadków przejawia się w sposobie prezentacji, a nie określeniach komentujących. ${ }^{5}$

Nieistotne w tym wypadku jest ukazanie wszystkich faktów, ale wyselekcjonowanie tych najważniejszych, pokazanie problemu nawet poprzez niedopowiedzenie niektórych szczegółów, by odbiorca miał możliwość ostrzejszej percepcji prezentowanego zjawiska. ${ }^{6}$

Jeśli porównać feature $\mathrm{z}$ reportażem - feature to szkic (jak chce tego definicja słownika oksfordzkiego), ${ }^{7}$ a więc forma prostsza, niewymagajaca od autora wywoływania nastroju, charakterystyki bohaterów i środowiska. Przywiazuje on bowiem wage do pokazania głównych zarysów zagadnienia. $^{8}$

Normy estetyczne oraz cechy strukturalne reportażu i feature $z$ jednej strony łączy bardzo wiele, $z$ drugiej zauważa się różnice. Oba gatunki traktuja o danym, konkretnym wydarzeniu zawierającym w sobie element nowości i autentyczności. Wyeksponowanie pojedynczego wydarzenia i wyeliminowanie watków ubocznych sprzyja zwartej konstrukcji feature. W reportażu nadmiar elementów plastycznych, zarysowujacych

\footnotetext{
4 Wolny-Zmorzyński 2003, 71.

5 Tamże.

6 Tamże.

7 Oxford Dictionary 1964, 442.

8 Wolny-Zmorzyński 2003, 70.
} 
tło zdarzeń i charakteryzujących bohaterów, jest koniecznością, ${ }^{9} \mathrm{w} f e$ ature - nie.

W reportażu sztuka odtwarzania rzeczywistości zmusza reportera do stosowania reguł bliskich literaturze. W feature obrazy sa chronologicznie uporzadkowane, prezentowane zgodnie $z$ przebiegiem akcji. Brak w nim plastycznych opisów, ubarwiających wypowiedź reportera. Feature to nie uproszczenie gatunku, ale surowe trzymanie sie przez reportera rzeczywistości bez wywoływania atmosfery i nastroju prezentowanych zdarzeń. ${ }^{10}$ Feature to po prostu odpowiedź na zapotrzebowanie chwili - szybki przekaz; orientowanie odbiorcy w tym, co się gdzieś niedaleko niego wydarzyło.

Feature jest wygodne dla redakcji: nie zajmuje dużo miejsca w gazecie, nie zabiera redaktorowi czasu na przygotowanie materiału, bo wystarczy sygnalizować problem. Tekst jest oszczędny, ma być efektownie napisany.

Na szczęście $z$ techniki feature nie wszyscy reporterzy korzystają. To forma dla mało ambitnych i chcących konkurować szybkościa przekazu informacji $z$ mediami elektronicznymi (radiem, telewizja, Internetem). Feature wyraźnie stosowany w pismach, którym bardziej zależy na sensacji, może być uznany za reportaż i tak będzie pewno określany przez dziennikarzy, ale wyraźnie należy podkreślić, że różni się od reportażu, w którym najważniejszy jest człowiek i pokazanie jego problemu (w Polsce - reportaż literacki, ${ }^{11}$ we Francji reportaż wielki ${ }^{12}$ ).

Mimo rozwoju mediów elektronicznych, przy szczególnym zainteresowaniu odbiorców telewizja, wbrew pozorom reportaż pisany ma się dobrze. Jest także przedmiotem badań medioznawczych, językoznawczych, literaturoznawczych, a także samych dziennikarzy. ${ }^{13}$

Obecnie, po 1989 roku, dziennikarze, szukając najprostszych form mówienia o rzeczywistości, często zobligowani są przez pracodawców do kierowania się względami ekonomicznymi, a nie artystycznymi (oszczędność miejsca).

Na początku lat 90. XX w. obawiano się, że nadchodzi zmierzch reportażu. Jednak Małgorzata Szejnert, kierownik działu reportażu w „Gazecie Wyborczej”, stworzyła w tym czasie szkołę reportażu. Wyszło z niej wielu reporterów dziś znanych i uznanych, m.in. Mariusz Szczygieł, Wojciech Tochman, Wojciech Jagielski, Beata Pawlak, Jacek Hugo-Bader, Lidia Ostałowska.

9 Tamże, s. 68-71.

10 Tamże.

11 Por. Wolny-Zmorzyński 2004, 7-26.

12 Raboy 1995, 180 i 183.

13 Por. Wolny-Zmorzyński 2004, Furman, Kaliszewski, Wolny-Zmorzyński 2000, Rejter 2000, Wojtak 2004, Piechota 2002, Sztachelska 1997, Szydłowska 2001, Owsiany 1996. 
Małgorzata Szejnert podpowiadała młodym adeptom sztuki reportażu, by opierali się na tradycyjnych wzorach, by zwracali uwage na budowę tekstu, zarówno na treść, jak również konstrukcję zewnętrzną i wewnętrzna, a także by wychodzili naprzeciw oczekiwaniom współczesnego odbiorcy:

- tytuł ma przyciagać uwage czytelnika, ma być intrygujacy, jak w feature (np. Cygan to ja - Lidii Ostałowskiej; Niedziela, która zdarzyła się w środę- Mariusza Szczygła; Czekam pod adresem Berlin czy Jakbyś kamień jadła Wojciecha Tochmana);

- tekst (korpus) należy dzielić na wyraźnie zaznaczone części, osobno zatytułowane (śródtytuły), co ułatwia czytanie i porządkuje wiedzę odbiorcy o prezentowanych wydarzeniach tak jak w feature;

- tekst ma zestawiać fakty, opisywać bohaterów i środowisko plastycznie, by odbiorcy mogli sobie wyobrazić postacie i dane miejsca (obrazowanie, ale $z$ naciskiem na rysy szczególne bohaterów i miejsc, czyli znów podobnie jak w feature);

- tekst ma oddawać klimat zdarzeń poprzez wciaganie odbiorców w śledzenie zdarzeń $z$ punktu widzenia bohatera - iluzja uczestnictwa ${ }^{14}$ (chwyty literackie: patrzę na świat oczami postaci).

To reportażowe wzory zaczerpnięte $z$ Melchiora Wańkowicza, unowocześnione i z powodzeniem zastosowane jeszcze wcześniej przed 1989 rokiem m.in. przez Krzysztofa Kakolewskiego, Ryszarda Kapuścińskiego, Romualda Karasia, Jerzego Lovella, Dorotę Terakowska, Barbarę N. Łopieńska.

Najbardziej dziś popularny i znany - zmarły w 2007 roku - Ryszard Kapuściński (z ostatniego okresu można wymienić choćby Heban 2002 i Podróże z Herodotem 2004) - odbiega od szczegółowości na rzecz opisu problemu w taki sposób, by odbiorca miał wrażenie, że przeżywa go wspólnie $z$ bohaterami (gra między nadawca a czytelnikiem).

Samo prezentowanie faktów na zasadzie: oto one, proszę patrzeć, tak wyglądaja - odmiennie niż w feature - nie porywa odbiorcy. Fakty zaspakajaja jego ciekawość, ale nie pozwalają mu się zżyć z nimi. Sztuką jest więc pisanie reportaży w taki sposób, by zaprezentować problem widziany oczami bohaterów, obrazowo przedstawiać postaci i środowisko, $z$ którego się wywodzą. W takiej konwencji poetyckiej napisane sa reportaże autorstwa R. Kapuścińskiego, podobnie piszą: M. Szczygieł, W. Jagielski, pisały L. Ostałowska, B. Pawlak. Świat obserwowany oczami bohaterów staje się nam bliski, a zaprezentowane postaci znajome, ponieważ patrzymy na nie tak jak one same na siebie. I to jest sztuka reportażu.

W zmianie formy przoduje obecnie Mariusz Szczygieł. Stosuje on $z$ powodzeniem reportaże niewielkich rozmiarów w formie miniatury lub

14 Na podstawie badań reportażu w „Gazecie Wyborczej” oraz rozmów z reporterami, wychowankami Małgorzaty Szejnert. 
przypowieści, np. w zbiorze reportaży pt. Gottland [2006], lub zamieszcza tekst w tekście - jak w reportażu Projekt: prawda [2016], w który właczył cała - bez skrótów - powieść Stanisława Stanucha Portret pamięci z 1959 roku, by pokazać, jak reporter, „polując” na cudza prawdę i opierając się na niej, może się dowiedzieć czegoś więcej także o sobie samym.

Nie straciła nic na aktualności, a może jeszcze bardziej stała się popularna, forma prezentowania rzeczywistości z punktu widzenia bohaterów, czyli dopuszczania ich bezpośrednio do głosu, bez pośrednictwa reportera (polifoniczność wypowiedzi) dzięki literackiej Nagrodzie Nobla przyznanej za reportaż Swietłanie Aleksiejewicz. ${ }^{15}$ Znakomicie sprawdzaja się, stosujac tę polifoniczną formę reportażu, reporterzy tacy jak m.in. Marek Miller (np. reportaż o bazarze Różyckiego w Warszawie [2017]), Katarzyna Boni i Wojciech Tochman ( W mieście Ramta $\mathrm{z}$ tomu Kontener [2014]). Forma ta stosowana była $z$ powodzeniem przez Jacka Stwore w latach 70. ubiegłego wieku (m.in. Co jest za tym murem? [1977]) oraz przez Ryszarda Kapuścińskiego w Cesarzu [1976].

$\mathrm{Na}$ marginesie należy zaznaczyć, że podobnie wysoki poziom publikacji zachowały reportaże radiowe i telewizyjne. W natłoku faktów i zdarzeń dziennikarze popełniają błąd terminologiczny, określając newsy, wzbogacone o efekty dźwiękowe, reportażami. Podobnie jest w telewizji. Reportaże telewizyjne ${ }^{16}$ i radiowe, choć kieruja się odmienna poetyka niż reportaże pisane przed 1989 rokiem, różnią się wyłącznie tempem przekazu (dramaturgia) i krótszym czasem emisji, a prestiżowa nagroda „Prix Italia” dla najlepszego reportażu radiowego, wręczona we wrześniu 2004 roku Annie Sekudowicz i Annie Dudzińskiej z Polskiego Radia Katowice za reportaż Cena pracy o bezrobociu na Ślasku, świadczy niezbicie o wysokim poziomie polskiego reportażu radiowego. ${ }^{17}$

Reportażu telewizyjnego i jego poetyki przekazu, z zaznaczeniem, że bohater i jego problemy są najważniejsze, a nie zdawkowo prezentowane, bronia reporterzy telewizyjni, m.in. Ewa Borzęcka, Andrzej Fidyk, Krystian Przysiecki czy Irena i Jerzy Morawscy, Tomasz Patora. Pozwalaja wierzyć telewidzom, że nie liczy się tylko sensacja w przekazie medialnym, ale także szary człowiek i jego sytuacja.

Ogromna zmiana nastąpiła w sferze języka. Dominuje skrótowość, szybkość przekazu. To nie jest język wańkowiczowski, wzorowany na Sienkiewiczu. Nie ma już miejsca na długa frazę, rozbudowane opisy. Cechuje go dziś zwięzłość, trafianie od razu w sedno, nazywanie rzeczy po imieniu, wprost. Jako przykład można przywołać reportaże Marcina Kołodziejczyka $z$ tomu Bardzo martwy sezon. Reportaże naoczne [2016], które charakteryzuje dość obrazowa fraza, ale zdania sa krótkie, szybko

15 Swietłana Aleksiejewicz stosuje formę polifoniczności.

16 Guzek 1999, 187-197.

17 W 1972 roku Jacek Stwora nagrodzony „Prix Italia” za reportaż Pasja, czyli Misterium Męki Pańskiej w Kalwarii Zebrzydowskiej widziane. 
trafiają do świadomości odbiorcy, który potrafi się skupić na nich i na wynikajacym $z$ nich przekazie.

Zmiana nastapiła także w postawie reportera. Charakteryzuje go bezpośredniość, brak skrępowania w mówieniu o trudnych sprawach, co wiąże się obecnie ze zmianą obyczajów - pokazywaniu i nazywaniu wszystkiego wprost, wyciaganiu od bohatera najintymniejszych szczegółów z życia prywatnego: np. reportaże Mariusza Szczygła Projekt: prawda czy Bartosza Jastrzębskiego i Jędrzeja Morawieckiego Jutro spadna gromy [2015].

Od reportera odbiorca oczekuje obecnie nie tylko pokazania i ujawnienia problemów, ale wydobycia prawdy $z$ prezentowanych historii, dotarcia do przyczyn tragedii. Reporter stał się dzisiaj dla odbiorcy autorytetem, któremu się wierzy, stąd taka popularność gatunku (serie reportażu w wydawnictwach m.in. "Czarne”, „Wielka Litera”, „Znak”, „Dowody na Istnienie”), zastępuje dziadków, ojca, matkę, którzy byli kiedyś autorytetami, mówili, co widzieli, co przeżyli, gdzie byli. Reporterzy wypełnili tę pustkę, stali się głosem prawdy, nigdy fałszu czy samolubstwa ani kłamstwa, pomagaja także realizować pasje, podpowiadając na przykładach $z$ życia wziętych, jak dochodzić do celu.

Dzięki nośnikom (Internetowi) nastąpiła zmiana nie tylko w rozpowszechnianiu reportażu, ale jego tworzeniu. Internet zmienił formę reportażu pisanego na interaktywny - czytany na smartfonach. Tekst połączony ze zdjęciami i materiałami wideo, które uruchamiają się automatycznie w miare przesuwania się stron, zastosował Jacek Hugo-Bader [19 XII 2013] w reportażu Boskie światło o tragedii na Broad Peak. Technika tego reportażu wzorowana jest na reportażach przygotowywanych przez zespoły „New York Timesa” i „Guardiana” (najbardziej znany tego typu reportaż to SNOWFALL z „New York Timesa”"

Mimo zmiany nośników reporterowi przyświeca ta sama idea co wcześniej: pokazać to, czego nie widział ten, kto się chce o danej sprawie dowiedzieć.

Reportaż i reporterzy, korzystając obecnie z udogodnień technik medialnych, moga tylko rozwijać i udoskonalać formę przekazu. Reportaż był i jest gatunkiem potrzebnym, pozwala bowiem odbiorcy zrozumieć problemy innych, a dzięki temu i jego własne. Reportaż wzbogaca wiedzę o świecie, pokazuje ludzi i ich reakcje na różne, często trudne sytuacje, uczy, jak panować nad emocjami, jak przezwyciężać przeciwności losu, jak żyć. Reportaże sa lustrem, w którym odbijaja się sprawy odbiorców, ale widzą się oni jakby oczami innych, dlatego łatwiej im zastanowić się nad czymś, z czym może nie potrafią się uporać w danej chwili. Nabranie dystansu do problemu pozwala zatrzymać się nad sobą i odpowiedzieć

18 Michał Prysłopski, Boskie światło - pierwszy $w$ Polsce reportaż interaktywny, www.plio.pl 
na pytanie, co jest ważne. Reportaż był, jest i będzie świadectwem epoki, dokumentem dla następnych pokoleń.

Poetyka reportażu pisanego, w świetle rozwoju mediów i technik medialnych, świadczy niezbicie na jego korzyść, będzie on bowiem coraz bardziej spełniał, w dobie zalewu informacji, funkcję uzupełniająca do wiadomości prasowych i relacji, szerzej traktujac problem i prezentowane zjawiska oraz bohaterów. ${ }^{19}$

\section{ARTYKUE WIRALOWY}

Próżno szukać terminu artykut wiralowy w podręcznikach do gatunków dziennikarskich czy słownikach terminologii medialnej. Pojęcie to funkcjonuje wśród dziennikarzy pracujacych dla portali internetowych. Oznacza ono - w najprostszym ujęciu - tekst napisany w taki sposób, by nie tylko zainteresował odbiorcę, ale - w pełnym tego słowa znaczeniu dotkliwie wrył się w jego psychikę, wpłynął na niego, poruszył nim nawet do tego stopnia, by nie dawał spokoju i wymuszał dalsze dzielenie się $z$ dobyta wiedza na dany temat $z$ innymi odbiorcami, rozprzestrzeniał się jak wirus ( $z$ ang. viral) i zataczał coraz szersze kręgi wśród czytelników. To typowy gatunek dziennikarstwa internetowego, w szybkim tempie, niemal w czasie rzeczywistym, trafia pod wskazany adres, potem przesyłany jest dalej i dalej, w nieskończoność, do momentu, aż zainteresowanie nim w sieci wygaśnie.

Termin ten trafił do dziennikarstwa internetowego za sprawa marketingu wiralowego zwanego reklamą wiralowa, polegająca na swoistych planowych działaniach, wywołujących sytuacje, w których odbiorcy sami między sobą zaczynają rozpowszechniać wiadomości na temat usług, produktów czy firm. ${ }^{20}$ Podobnie ma się dziać $z$ tematem, który poruszany jest w artykule wiralowym.

Artykut wiralowy to termin pojemny. Może się w nim mieścić kilka gatunków dziennikarskich, pojęcie to bowiem używane jest zamiennie na określanie gatunków informacyjnych, m.in.: relacji, sprawozdania, reportażu, i publicystycznych, m.in.: artykułu publicystycznego, felietonu, komentarza, recenzji, czy wreszcie pogranicznych - szczególnie wywiadu. Trudno jest dlatego wyznaczyć jego cechy dystynktywne, jeśli chodzi o kompozycję (to zależy od konkretnego gatunku).

Artykuł wiralowy jest materiałem, tekstem, który ma „zarażać” odbiorców wyłącznie tematem. To właśnie interesująco przedstawiona treść jakiegoś zdarzenia, problemu, historii jest podstawowym wyznacznikiem tego gatunku.

19 Por. Haller 1997, 67.

20 Por. Rosiński 2012. 
Jak zatem opowiedzieć historię, jak przyciągnąc uwagę czytelnika do problemu, jak wpłynać na to, by zaprezentowane fakty wryły się $\mathrm{w}$ psychikę odbiorcy, by ten $z$ przejęciem nie tylko opowiedział komuś drugiemu o tym, czego sie dowiedział $z$ artykułu, ale przede wszystkim polecił go innym w lawinie przeróżnych informacji, płynacych $z$ portali internetowych, zalewie wiadomości z kraju i ze świata, o których potencjalny czytelnik chciałby się od razu wszystkiego dowiedzieć, nagle, po wejściu na daną stronę internetową? Co wybrać $z$ ogromu materiałów, czym się zainteresować, co pominąć, a czego nie zlekceważyć? Co zatem może zdecydować o tym, że tekst zawładnie odbiorcą?

Pierwsza cecha to tytuł. Ma być jak magnes, przyciagać uwagę. To wizytówka całości tekstu, zapowiedź czegoś interesującego, zwrócenie uwagi na istotny problem. To też pierwszy kontakt czytelnika $z$ materiałem, który już musi go „zainfekować”.

Już w badaniach literaturoznawczych zwracano uwagę na to, że czytelnik kieruje się najczęściej tytułem, podejmując lekturę ${ }^{21}$ tekstu. Jego stosunek do treści powinien się wiąać $z$ intencjami autora, któremu zależy na uwypukleniu problemu, podkreśleniu istotnych zjawisk, które to właśnie tytuł wysuwa na plan pierwszy. Tytuł artykułu wiralowego ma od razu działać na psychikę i uczucia odbiorcy, pobudzać ciekawość jak później cały tekst, np. 8 października 2019 roku w Onecie.pl moglišmy znaleźć następujące tytuły:

Nauczycielowi dał $w$ twarz, rzucał ławkami;

Biedron ratowat 2-latka $z$ płonacego auta;

Pierwszy zarzut $w$ sprawie molestowania żołnierki w Żandarmerii Wojskowej.

To nie krój czcionki tytułu artykułu wiralowego czy jej wielkość „krzyczą", ale intrygująca zbitka słów, imiona i nazwiska celebrytów, o których czytelnik chce się czegoś dowiedzieć, cytat $z$ wypowiedzi znanego polityka, który nawiazuje do drażliwej przeszłości, tytuły w formie pytania, wzmagające dociekliwość, przyciagają uwage internauty, wyzwalają w nim emocje: ciekawość, radość, wściekłość, przerażenie, irytację, oburzenie, gniew, ${ }^{22}$ ponieważ tytuł jest środkiem emotywnego nastawienia odbiorcy do tekstu.

Do napisania artykułu wiralowego - jak i każdego innego - potrzebna jest dobra znajomość tematyki, oczytanie, rozmowy z ludźmi, zbliżenie się do nich, umiejętność plastycznego odtwarzania zdarzeń. Samo zbieranie materiału związane jest $\mathrm{w}$ większości sytuacji $z$ przyjemnościami, poznawaniem interesujących przygód, czasem wszakże także $z$ niebezpiecznymi zdarzeniami, w których znajdzie się dziennikarz. Opowiedzenie o tym samo w sobie może elektryzować zarówno nadawcę, jak i odbiorcę,

21 Por. Markiewicz 1977, 21.

22 Por. Berger, Milkman 2011, 2-4. 
choć nie zawsze może wszystkich „zarazić”. Przecież zdarza się i tak, że sa osoby odporne na tego typu działania, czym dziennikarz - w tym wypadku - raczej się nie zniechęca.

Dziennikarza redagującego artykuły wiralowe charakteryzuje spostrzegawczość, zmysł obserwacyjny, znajomość psychologii, celny dowcip, dzięki czemu wpływa na uczucia odbiorców. W kompozycji najważniejsze sa dwa pierwsze akapity artykułu wiralowego. To ich treść chwyta czytelnika „za gardło”, a następnie trzyma w napięciu do końca tekstu. Autorzy osiagają sukces, gdy stosują krótkie zdania, używają języka potocznego, plastycznego, wywołującego w świadomości odbiorcy obrazy, które umie on sobie wyobrazić.

Autorzy artykułów wiralowych unikaja przymiotników takich jak np. fenomenalny, majestatyczny, szokujacy, wyśmienity, obrzydliwy. To wynika $z$ treści i opisanych sytuacji, że coś jest fenomenalne, wspaniałe, wyśmienite, odrażające. Autorzy pokazują (!) zdarzenia, sprawiają iluzję rzeczywistości, by odbiorca miał wrażenie, że uczestniczy w przedstawianych historiach. Najważniejsze jest w nim owo pokazanie (!), a więc obrazowe ujęcie tematu, omówienie faktów, zastanawianie się nad nimi wspólnie $z$ czytelnikiem. Aktualna jest w tym wypadku rada Melchiora Wańkowicza, który ucząc córkę Martę pisania, zalecał:

- Przecież nie idziesz na referenta Urzędu Pocztowego, żebyś miała wszystko po kolei opisywać. Cóż to lekcja, aby zbyć, czy pisanie? Natęż się panna: nie masz prawa pisać, nim nie wywołasz obrazu. Masz opisywać, a nie referować. ${ }^{23}$

Najważniejsze w artykule wiralowym jest plastyczne zaprezentowanie problemu, które ma się wyłaniać $z$ opowieści dziennikarza, będącego gospodarzem, oprowadzającym odbiorców po tematach, które sam wcześniej dobrze poznal, dysponuje faktami i tak je dawkuje, by wzmagać zaciekawienie odbiorcy. Efekt taki osiagga się dzięki stosowaniu wartkiej opowieści, ilustrowanej celnymi przykładami z życia bohaterów, które maja być w taki sposób zaprezentowane, by czytelnik umiał się do nich sam ustosunkować.

Autorzy artykułów wiralowych przywołują często bezpośrednio krótkie wypowiedzi opisywanych osób $\mathrm{w}$ formie cytatów lub dialogu $z$ innymi bohaterami, co w pewnym sensie także zbliża te postaci do odbiorców. Przeciwstawiają także kontrowersyjne wypowiedzi dwóch, trzech bohaterów, co wzmaga również zainteresowanie i naświetla problem $z$ kilku punktów widzenia. Dziennikarz tym samym zwolniony jest tu $z$ charakterystyki postaci. Przywołuje jedynie dane bohatera (inicjały, imię i nazwisko, wiek), który mówi „od siebie”, sam charakteryzuje zdarzenie w sposób nawet emocjonalny, ocenia innych. Autor - w pewnym sensie - jest zwolniony w takim wypadku $z$ obowiazku zachowania poprawności

23 Wańkowicz 1983, 122. 
językowej, bowiem prezentuje „żywą” wypowiedź bohatera, która nigdy nie jest wolna od potknięć stylistycznych.

$\mathrm{W}$ artykułach wiralowych dziennikarz jest $\mathrm{z}$ jednej strony prokuratorem, poszukującym przyczyn danego postępowania bohatera i analizującym je, $z$ drugiej - także jego adwokatem. W końcowych akapitach tekstu natomiast zachowuje się jak sędzia, który zajmie określone stanowisko.

Artykuły wiralowe cieszą się obecnie ogromnym powodzeniem wśród odbiorców nie tylko portali internetowych, ale i gazet codziennych oraz czasopism. Ich forma raczej jest prosta, treść trafia od razu do wyobraźni czytelnika. W pierwszym akapicie dziennikarz chronologicznie przywołuje pobieżnie fakty po to, aby w następnych analizować zaprezentowana wcześniej historię, pokazuje dokumenty, którymi dysponuje, omawia je zdawkowo, by zastanowić się razem $z$ czytelnikiem, jakie sa przyczyny powstania problemu, $z$ którym bohaterowie nie umieja sobie poradzić. Nie chodzi tu o głębokie dociekania, ale o naświetlenie zjawiska $z$ różnych stron i jego analizę. Obecnie czytelnicy w nadmiarze faktów i spraw dziejących się wokół nich mogą czuć się zagubieni (tzw. szum informacyjny $z$ powodu sporej ilości newsów), więc takie wyjaśnianie faktów i przyczyn postępowania prezentowanych bohaterów spotyka się $z$ dużym zainteresowaniem.

W artykułach wiralowych autor bierze na siebie odpowiedzialność za opinie, które wydaje. Musi więc tę analizę zjawiska przeprowadzić dokładnie i tak argumentować swój punkt widzenia, by był zgodny $z$ jego przekonaniami i sumieniem.

Artykuły wiralowe ilustrowane są często bogatym materiałem fotograficznym. Tematy fotografii i osoby prezentowane na nich muszą być rozpoznawalne - jak chce Robin Good, autor poradnika dla fotoedytorów - błyskawicznie. Odbiorca nie może zastanawiać się, co na nich widać, ale ma wiedzieć od razu, co widzi i dlaczego widzi prezentowany obraz. ${ }^{24}$

Fotografie oddaja nastrój i wzmagaja dramatyzm opisywanych wydarzeń, wpływaja dodatkowo na wyobraźnię odbiorcy i pomagaja mu „zrosnać się" z prezentowanym materiałem, przenikaja do jego psychiki, wyzwalają uczucie podziwu lub odrazy do kogoś lub czegoś, z kim i z czym się zapoznaje w tekście głównym. Każda fotografia połączona $z$ tekstem artykułu sugeruje także jego interpretację, pomaga wyobrazić sobie miejsca, na których dane historie się rozgrywaja, przybliżaja bohaterów, którzy stają się od razu rozpoznawalni, a tym samym bliżsi odbiorcy.

W fotografiach, będacych ilustracją artykułów wiralowych, chodzi wyłącznie o realizm i pokazanie prawdy zastanej sytuacji bez retuszu, zarejestrowanej bez aranżacji. Potwierdzają one prawdziwość przywoływanych historii i zdarzeń. Dzięki fotografiom odbiorca widzi opisywany swiat.

${ }^{24}$ Por. Good 2007. 


\section{PODSUMOWANIE}

Tak jak przed 1989 rokiem teksty dziennikarskie były raczej kierowane do wykształconego odbiorcy, który umiał zrozumieć wiele podtekstów, niedomówień i aluzji, tak obecnie autorzy reportaży i artykułów wiralowych mówią wprost o rzeczywistości i świecie, który ich otacza, stosuja najprostsze rozwiazania i środki stylistyczne, by jak najszybciej trafić do wyobraźni odbiorcy, a tym samym do jak najszerszego grona czytelników. Sprzyja temu także rozwój technik medialnych (Internetu, fotografii), co dodatkowo pozwala wywoływać u odbiorcy wrażenie, że prezentowane problemy dotyczą także jego samego i potrafi się on w nich odnaleźć. Uproszczenie formy, prostota języka, wskazywanie na sensacyjne tematy wynikaja $z$ potrzeby zdobycia rynku. Ekonomia obecnie dyktuje warunki formalne. Czy ta ewolucja daje poczattek rewolucji? Trudno powiedzieć.

\section{Bibliografia}

W. Bereś, 2000, Czwarta władza. Najważniejsze wydarzenia medialne III RP, Warszawa.

J. Berger, K.L. Milkman, 2011, What Makes Online Content Viral?, „Journal of Marketing Research", www.jonahberger.com/wp-content/uploads/2013/02/ViralityB:pdf

S. Burkot, 1984, Proza powojenna 1945-1980. Analizy i interpretacje, Warszawa.

W. Furman, A. Kaliszewski, K. Wolny-Zmorzyński, 2000, Gatunki dziennikarskie. Specyfika ich tworzenia i redagowania, Rzeszów.

R. Good, 2007, How To Select Appropriate Images For Publication, www.masternewmedia.org/independent_publishing.htm

M. Guzek, 1999, Nowe formy reportażu (dokumentu) $w$ telewizji [w:] W. Furman, K. Wolny-Zmorzyński (red.), Poetyka i pragmatyka gatunków dziennikarskich, Rzeszów, s. 187-197.

M. Haller, 1997, Die Reportage. Ein Handbuch fuer Journalisten, Konstanz.

J. Kleiner, 1990, Zarys dziejów literatury polskiej od poczatków do 1918 roku, Wrocław-Warszawa-Kraków.

H. Markiewicz, 1997, Tytuly u Żeromskiego [w:] H. Markiewicz (red.), W kręgu Żeromskiego, Warszawa.

H. Markiewicz, 1999, Pozytywizm, Warszawa.

R. Matuszewski, 1992, Literatura polska 1939-1991, Warszawa 1992.

Oxford Dictionary: The Concise Oxford Dictionary of Current English, 1964, Oxford.

E. Owsiany, 1996, Uleczyć życie, szkic o reportażu [w:] A. Niczyperowicz (red.), Abecadło dziennikarza, Poznań, s. 19-36.

M. Piechota, 2002, Jaka Ameryka?, Lublin.

M. Prysłopski, 2014, Boskie światło-pierwszy $w$ Polsce reportaż interaktywny, www.plio.pl 
M. Raboy, A. Roy, 1995, Les medias quebecois. Presse, radio, television, cablodistribution, Montreal-Paris-Casablanca.

A. Rejter, 2000, Kształtowanie się gatunku reportażu podróżniczego w perspektywie stylistycznej i pragmatycznej, Katowice.

W. Rosiński, 2012, Reklama w e-biznesie bez tajemnic, „Gazeta Małych i Średnich Przedsiębiorstw" nr 1(117) z 9.01.2012 roku.

J. Sztachelska, 1997, Reporteryje i reportaże. Dokumentarna tradycja polskiej prozy II połowy XIX wieku i poczatku XX wieku, Białystok.

J. Szydłowska, 2001, Warmia i Mazury w reportażu polskim 1945-1980, Białystok.

J. Święch, 1997, Literatura polska w latach II wojny światowej, Warszawa.

M. Wańkowicz, 1983, Ziele na kraterze, Warszawa.

M. Wojtak, 2004, Gatunki prasowe, Lublin.

K. Wolny, 1991, O poetyce współczesnego reportażu polskiego 1945-1985, Rzeszów.

K. Wolny-Zmorzyński, 2003, Reportaż a feature - próba charakterystyki porównawczej, „Zeszyty Prasoznawcze” nr 1-2, Kraków.

K. Wolny-Zmorzyński, 2004, Reportaż-jak go napisać?, Warszawa.

\title{
Evolutions and revolutions in selected journalistic genres after 1989 (a reportage and a viral article)
}

\author{
Summary
}

Over the past three decades, under the influence of the development of electronic techniques and changes in the awareness of media recipients arising from the freedom of speech, reportage has evolved and a new genre, i.e. a viral article, has occurred. After 1989, reporters, relishing the hint of freedom, began to depart from the habits of the passing (authoritarian) epoch and make changes to the poetics of the genre. These changes concern the following spheres: the topic taken up by reporters; the form (structure, shape); the language; the reporter's attitudes; the media. Before 1989, journalistic texts had been addressed to the educated reader who was able to understand many overtones, understatements, and hints, and currently, authors of reportages and viral articles talk about the reality and the world surrounding them in a straightforward manner, apply the simplest stylistic solutions and devices in order to find the shortest way to the recipient's imagination, and thus to the largest possible group of readers.

Keywords: journalistic - freedom - reportege - viral article - new genre.

Trans. Monika Czarnecka 